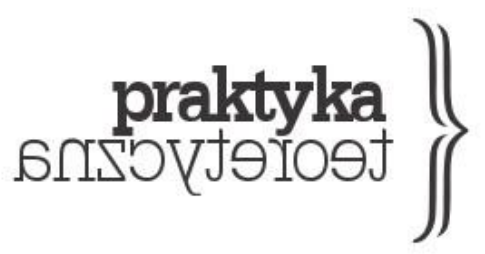

ISSN 2081-8130

DOI: $10.14746 /$ prt.2018.2.6 www.praktykateoretyczna.pl

\title{
POSSIBILITY OF SCIENCE, IMPOSSIBILITY OF MIRACLES: LÉON BRUNSCHVICG AGAINST QUENTIN MEILLASSOUX
}

\author{
TRYGGVI ÖRN ÚLFSSON
}

\begin{abstract}
The article argues that, while Quentin Meillassoux's project, undertaken in After Finitude, merits attention, since the French philosopher is right that faith in sciences' capacity to open up new domains to thought must be restored, the solutions he offers have two serious shortcomings. 1) His depiction of science as the producer of ancestral statements does not capture satisfactorily the essence of scientific creativity. 2) The claim that everything is necessarily contingent is fundamentally incompatible with scientific knowledge. The article, then, contrasts Meillassoux's principle of the necessity of contingency with a principle that is extracted from the historical epistemology of Léon Brunschvicg and Antoine-Augustin Cournot. Instead of a principle of unreason, the article defends a principle of a metamorphosing reason founded on the practical impossibility of irreducible contingency.
\end{abstract}

Keywords: Meillassoux, Brunschvicg, Cournot, contingency, causality. 
One of the more important contributions to one of the most prominent movements in contemporary philosophy is Quentin Meillassoux's attempt to ground the possibility of objective scientific knowledge. The movement in question - usually referred to as speculative realism ${ }^{1}$ - could be said to draw its name from the two aspects of such a project: it is realist because it is first and foremost interested in mind-independent entities; it is speculative because its access to mind-independent entities is based on pure reasoning. In After Finitude $(2008)^{2}$, Meillassoux lays the groundwork for his contribution, framing the problem of the objectivity of sciences as the problem of ancestrality. This neologism is defined as "any reality anterior to the emergence of the human species - or even anterior to every recognized form of life on earth" (Meillassoux 2008, 10). By showing the existence of ancestral scientific statements - for instance statements belonging to theories about the origin of our planet Meillassoux's aim is to debunk what he labels as correlationism, which, according to his estimations, has been enjoying hegemony within the philosophical field since Kant's socalled Copernican revolution. "By »correlation« we mean the idea according to which we only ever have access to the correlation between thinking and being, and never to either term considered apart from the other." (Meillassoux 2008, 5) Meillassoux's idea is that, by demonstrating that it is possible to think of something devoid of any thought, he can save science from the limitations imposed on it by Kant and his successors - basically everyone from Hegel and Heidegger to Deleuze and Wittgenstein. Far from provoking a second Copernican revolution, Kant is responsible for a Ptolemaic counter-revolution in which the possibilities opened up by the first Copernican revolution are closed once more.

But - and this is the speculative part of speculative realism - Meillassoux does not pursue his defence of the revolutionary qualities of modern science through an analysis of its methods or results, but through the application of pure reason, by logically demonstrating new ancestral statements to be added to the scientific corpus. The most important of these is

\footnotetext{
1 Some of its other main contributors (not all of which, however, identify as speculative realists) are Ray Brassier, Graham Harman, Markus Gabriel, Levi Bryant and Manuel de Landa. For an introduction to speculative realism, see Leon Niemoczynski 2017. For an autopresentation of speculative realism, see Tristan Garcia and Pierre-Alexandre Fradet 2016.

2 Although published in 2005, After Finitude is to this day Meillassoux's latest substantial theoretical testament. In Graham Harman's Quentin Meillassoux: Philosophy in the Making (2011), a translation of a significant part of a reworked version of Meillassoux's doctoral thesis, L'inexistence divine, is published. Although Meillassoux has stated that his reworking of his thesis constitutes a work in progress in which his theoretical commitments should be developed more fully, the bits that appear in Harman's book are said to be from 2003, two years prior to the release of After Finitude, and include in a barely altered form the main ideas of the latter work. His other major published works, the Number and the Siren: A Decipherment of Mallarmés Coup de Dés (2012) and Science Fiction and Extra-Science Fiction (2015), must be regarded as sidesteps.
} 
his demonstration of the necessity of contingency, or the principle of unreason. Meillassoux purports to show that absolutely anything is possible, except contradictions and a couple of necessary truths. By this, he accomplishes two things: 1) against the correlationist argument that everything is mind-dependent, he shows that the principle of unreason and its derivatives are not; 2) he grounds all (other) ancestral scientific statements, since the possibility of almost everything should include the possibility of every scientific fact.

I propose that there are two reasons to be interested in Meillassoux's project. 1) I believe, as he does, that there has been a divorce between science and philosophy, where philosophers can freely pursue their activity without taking into account even basic results of modern science - and that this divorce can be traced back to the shortcomings of Kant's critical project. 2) I believe, like Meillassoux, that, for the overcoming of this divorce, the question of contingency is one of the more important ones. However, I will try to show that the problem is both badly defined in terms of ancestral statements and badly solved with a demonstration of the necessity of contingency. Lastly, I will try to see, with the help of two other French philosophers, Léon Brunschvicg and Antoine-Augustin Cournot, what it would take to redefine the problem and to work towards a solution.

\section{The problem of ancestralities}

Let us first draw forward more fully the meaning of the problem of ancestralities in After Finitude. As already mentioned, Meillassoux introduces ancestralities as a touchstone against which correlationism necessarily fails. What is familiar to any scientist - namely, a reality unrelated to humans - is for most philosophers simply unthinkable. But what explains this discrepancy between science and philosophy, which manifests with the problem of ancestralities? The central argument that Meillassoux attributes to correlationists is what he calls the argument of "the correlationist circle" (Meillassoux 2008, 30): every experience of mind-independent reality is always someone's experience, and thus a correlation between the reality and the someone. In terms of German Idealism: every in-itself, insofar as access to it is granted, is only ever an in-itself-for-us. Meillassoux likes to cite Hegel's saying that one cannot "creep up on" the object "from behind" (Meillassoux 2008, 4; Hegel 1977, 54 (\$ 85)) in order for it to reveal itself as it was prior to one's encounter with it.

But it seems that if we understand correlations in this sense, then ancestralities could not be anything but correlations. Scientists, including those studying the early periods in the history of the universe, are indeed someones and their discoveries or theories are indeed 
their discoveries and theories, and so cannot be anything but correlations between themselves and the alleged ancestral reality. How could Meillassoux deny this?

It seems that he introduces Locke's and Descartes's distinction between primary and secondary qualities in order to covertly alter the meaning of correlations. Locke and Descartes call secondary those qualities that can be analysed as the effects of a relation between a thinking being and a thing, such that the thing produces the quality in the thinking being $^{3}$. A few examples are pain, smell, colour and harmonious melodies. In Meillassoux's words: "Remove the observer, and the world becomes devoid of these sonorous, visual, olfactory, etc., qualities, just as the flame becomes devoid of pain once the finger is removed." (Meillassoux 2008, 1) So for the correlationist, according to Meillassoux, secondary qualities are simply the only qualities there are.

For the scientist working within the framework of modern science, on the other hand, there are also primary qualities, viz., qualities that are not the effect of a relation between two or more things but inherent in things considered separately from other things as their properties, like an attribute in relation to a substance. It is clear that it is not only a question of the classical subject-object correlation that prompts this negative definition of primary qualities, since in his treatment of correlationism Meillassoux includes what he calls an "absolutisation" (Meillassoux 2008, 37) of the correlation, viz., a radicalisation of correlationism in which the correlation becomes a transcendental principle treated as independent of and more fundamental than any disclosure of a reality relative to a subject, as in Deleuze's vitalism or Schopenhauer's voluntarism. So primary qualities, as Meillassoux rethinks them, cannot be any sort of relational qualities, lest he become a correlationist himself. They are not atoms either, as one would think given their separate nature, but rather anything that can be measured by geometrical and arithmetical tools. According to Meillassoux's historiography, modern science was born when nature was finally inserted into a space without any privileged point of view, contrary to Aristotelian physics, which was structured around man's point of view construed as the centre of the universe (Meillassoux 2008, 136-137). The non-relationality manifests itself as the absence of a centre to which everything in it could be correlated.

There is thus a fundamental ambiguity in Meillassoux's presentation of correlationism. On the one hand, correlationism is considered as an epistemological thesis, almost an epistemological tautology: we cannot know anything about a supposed object as it subsists in-itself independently of how we relate to it. On the other hand, it is considered

\footnotetext{
3 See John Locke (1979, 114-25 (book 2, chapter 8)) and René Descartes (1985a, 50-62 (Sixth Meditation); 1985b, 223-4 (Part 2, SS 1 and 4)). Meillassoux makes clear that he is not interested in the particularities of Locke's and Descartes's respective treatments of the distinction, but only in "a sense that seems to be common to both" (Meillassoux 2008, 129).
} 
as an ontological thesis: that a world without thought, like the one presented in modern physics, is impossible and even unthinkable ${ }^{4}$. As Meillassoux puts it: 'The world is meaningful only as given-to-a-living (or thinking)-being.' (Meillassoux 2008, 15) The second thesis is much stronger and less plausible and, at the very least, does not follow from the argument of "the correlationist circle". There is no reason that a correlationist - whose theory is defined by Meillassoux in terms of access - should decree on the ontological or logical possibility of a world without living beings which is considered regardless of its accessibility. Her only caveats would be 1) that such a world would have to be correlated to some observers in order to become the object of a scientific theory and 2) that the correlation could later become an object of scrutiny and suspicion, giving rise to the problem of a possible discrepancy between phenomena and things in themselves. So, it is only by conflating the two versions of correlationism - epistemological and ontological or logical - that Meillassoux can present ancestral statements as a problem for correlationism.

\section{The solution of necessary contingency}

But although the problem of ancestrality proves to be a pseudo-problem, the solution to that problem, albeit equally dubious (as will become clear), is of some interest. Meillassoux's solution goes by way of a demonstration of a principle that negates Leibniz's principle of sufficient reason and that Meillassoux names accordingly the principle of unreason: "There is no reason for anything to be or to remain the way it is; everything must, without reason, be able not to be and/or be able to be other than it is." (Meillassoux 2008, 60) This principle conveys the meaning of the necessity of contingency. Since it results from a formal demonstration, its validity is necessary and absolute. But its content prescribes the nonnecessity of everything subsumed under it - and thus the principle cannot apply to itself. So, since nothing is necessary except the very fact that nothing is necessary, almost everything must be possible, including the suspension of all the natural laws that humans have come to know.

It seems that this principle of unreason constitutes a solution to the problem of ancestrality only by virtue of it being absolutely necessary, which entails that it does not

${ }^{4}$ In Nibil Unbound: Enlightenment and Extinction (2007, 59-60), Ray Brassier draws forward this ontological aspect of correlationism as it is conceptualised by Meillassoux. As Brassier remarks, the correlation is in fact understood as only a particularly significant historical event: "some sort of fundamental ontological rupture, shattering the autonomy and consistency of reality, such that once consciousness has emerged on the scene, nothing can pursue an independent existence any more". See also Dan Zahavi's discussion of Brassier's interpretation $(2016,296)$. 
depend on any correlation. Its demonstration is indeed founded on the non-validity of correlationism. The form of the demonstration is that of a reductio ad absurdum. To show that the principle of unreason is absolute, Meillassoux supposes hypothetically the validity of correlationism according to which nothing is absolute. But, from the validity of correlationism, one can derive the validity of the principle of unreason and thus the nonvalidity of correlationism. The hypothesis leads to a contradiction and must therefore be rejected. The core of the argument is that in order to refute the absolutisation of correlationism - i.e. the idea that correlation is a property of things in themselves - the correlationist has to suppose the possibility of non-correlation and thus also the possibility of the non-existence of the terms of the correlation. But by doing so, she has trespassed the limit that separates the correlation from the ancestral, the for-us from the in-itself, because she has admitted the possibility of a reality without thought - which is what ontological correlationism excludes. So Meillassoux's argument boils down to the claim that the principle of unreason "is an absolute that cannot be de-absolutized without being thought as absolute once more" (Meillassoux 2008, 58).

However, even on this formal level, the argument is insufficient. It can be granted that ontological correlationism cannot disprove absolutised ontological correlationism without thereby allowing the existence of something absolute, but this absolute does not have to be the principle of unreason. It could be the case that some things were possible in an absolute sense and others not, or that some things had sufficient reasons for their existence, while others were unfounded, etc. Moreover, if correlationism is construed epistemologically, then there is no reason to exclude the possibility that absolutised ontological correlationism could be true. By virtue of what access to being-in-itself could the correlationist judge the validity or the non-validity of absolute correlationism? Obviously none.

\section{The problem of the solution}

There are, however, deeper problems still that Meillassoux's solution to the problem of ancestrality stirs up. The first problem is so obvious that Meillassoux cannot elude it. In After Finitude, he presents it as the "problem of Hume". In its original form, it is the problem of inferring the necessity of the laws of nature without presupposing their validity and thereby begging the question (petitio principii). For Meillassoux, it takes on a slightly different form. He asks himself how to pass from the uniformity of experience - or the seeming submission of singular events to general laws - to the necessity of those laws, and deploys quite sophisticated instruments in order to show that this submission is, after all, only mere 
semblance. In short, in his critical analysis of the Kantian solution - that the necessity of natural laws is a presupposition without which representation and consciousness would not be possible - Meillassoux exhumes the hidden assumption that possibilities must necessarily be totalisable, i.e. that there is a given quantity of possible states of affairs. But, after set theoretical demonstrations of the necessary incoherence of all ultimate totality, which recollects everything thinkable within the set theoretical universe, such an assumption and thereby also Kant's solution as a whole - can no longer be regarded as self-evident. Applying Occam's razor, Meillassoux concludes that the unnecessary assumption of the necessity of natural laws must be rejected. ${ }^{5}$ His solution for the problem of Hume is thus rather a refusal of the problem, since, contrary to Hume, he does not seek to found the necessity of natural laws. For Meillassoux, the necessity is more essentially a contingency wrongly inferred from the regularity of experience. It is quite disappointing that he does not at any point attempt to explain why experience presents itself uniformly despite the absolute possibility of wholly chaotic experience.

It is indeed through the concept of explanation that the weakness of Meillassoux's solution can be identified. Although the contingency of natural laws may be compatible with the uniformity of experience, it is wholly incompatible with scientific explanation. The practice of natural sciences such as physics or chemistry cannot be reduced to the mere registration of measurable facts, because science is essentially the art of anticipation - the elaboration of theories that account for the heterogeneity between former theories and singular events giving rise to a practice of verification. There surely are many different ways of describing and accounting for scientific practice, but it is clear that any such description must include some form of correlation between past and future, without which a true understanding of scientific objects is impossible. Even though Kant's analogies of experience are not logically deduced from any already-given concept of representation, it seems impossible to conceive of science without any form of anticipation by which change and identity are correlated, as in Kant's first analogy. But if everything that happens, despite its relative regularity, is purely contingent, any form of explanation by which a future event becomes understandable in light of a past one and a common principle is simply impossible. And so is any possibility of science.

The inadequacy of Meillassoux's solution from the point of view of scientific practice is maybe clearest in the role he attributes to mathematics in ancestral science. As already described, he understands science as the practice of measuring extended things using the tools of geometry and arithmetic. A scientific object is determined by attributing spatial dimensions and quantifiable qualities such as size and weight. But even such

\footnotetext{
${ }^{5}$ For the longer version of Meillassoux's demonstration, see Meillassoux 2008, 93-108.
} 
a schematic account of scientific practice is incoherent with the principle of unreason. Without the correlation between numbers or laws according to which sequences like that of the natural numbers can be produced, arithmetic numbers lose their intelligibility and thus also their use. Therefore, a given arithmetical fact cannot be unrelated to other arithmetical facts in the way that the principle of unreason requires. Moreover, qualities studied in modern physics are usually determined by their implication in functional relationships. In Newtonian physics, for instance, weight is a function of mass and acceleration. Again, a given quantity cannot be determined outside of its relationship, i.e. its correlation, with other quantities as the principle of unreason would require.

Another problem seems to have escaped Meillassoux's attention. It stems from the demonstrative strategy he resorts to. Meillassoux's project is essentially of a foundational nature. Contrary to Kant, he does not attempt to found the necessity of natural laws, but he does try to found the absolutely necessary non-necessity of those laws. The available instruments for such a foundation cannot be borrowed from science, since it is the possibility of ancestral science that is at stake: they must necessarily be a priori. But, as in Kant's case, these instruments actually emanate from a particular science, the science of logic. To hide that fact, Meillassoux must fix the rules of logic by interpreting them not as the results or conditions of particular scientific practices, but as the eternal structure of "thought" or "reason"6. As a result, he produces stricter limitations on scientific practice than those he attributes to correlationism, by imprinting on any possible scientific result the psychological structure of faculties of thought, such as reason, understanding and sensibility. What is more, it is unclear why the principle of unreason does not apply to the rules that govern the argument that leads to its discovery. Should the principle of unreason not invalidate even the most elementary forms of reasoning that cannot but connect - correlate - premises to conclusions?

From a critical point of view - including Kant's own to some extent, who saw at the heart of reason, viz., in axiomatised geometry, the necessary presence of data originating from sensibility ${ }^{7}-$, logical structures are only fragile syntheses to be re-examined by future science. Thus, the Aristotelian syllogistic that defined the logical structure of science for centuries has given way to a more complete logic that allows for different axiomatic systems of which the syllogistic is only one possible system. For a coherent critical philosophy cannot presuppose a particular a priori structure of thought without reducing in advance the dynamic qualities of thought. Such were the errors of classical empiricism and classical rationalism alike, which hypostasised either the structure of sensibility or the structure of

\footnotetext{
${ }^{6}$ See in particular Meillassoux 2008, 90-91, where Meillassoux affirms that reason does not know any other a priori than that of the law of noncontradiction.

${ }^{7}$ See Brunschvicg 1922, 266 (\ 126) and Kant 1992, 396-397 (2.402-3).
} 
the understanding - thus both failing to capture the dynamic interrelation between the two faculties. Kant's most precious insight, on the other hand, is realised in his research into the cooperation of heterogenous intuitions in the construction of experience; for instance, into the role of Euclidean space in constructing our world of sensuous experience. Inversely, Meillassoux's speculative philosophy is the proof of how easily the refusal of critical philosophy can lead to a more radical unconscious correlationism.

\section{Towards a real problem and a real solution}

My aim in what follows is of course not to solve all the problems that Meillassoux's work raises, or even those that it should have raised. Nevertheless, I would like to reflect on what a solution to the problem of Hume requires in order to make authentic scientific knowledge possible. But first it must be made clear what such a solution implies. It cannot imply, as Meillassoux proposes, a deduction, respecting the rules of logic, of the metaphysical conditions of particular scientific statements such as ancestralities. It must rather, following the critical intuition, be drawn from an analysis of scientific activity leading to the uncovering of its conditions. However, due to Kant's excessive reliance on the logical canon derived from Aristotle, at the expense of the analysis of the concrete and historical study of the construction of various scientific theories, his works do not offer the best access to such a critical intuition. ${ }^{8}$ Nor is this intuition to be found in the works of his official inheritors the likes of Hermann Cohen or Ernst Cassirer - for their interpretation of critical philosophy puts the focus on the formal and systematic aspects of knowledge and excludes every psychological attempt to make the construction of scientific formal structures intelligible? I propose that the work of French philosophers working within the tradition of historical epistemology are more helpful than Kantian and Neo-Kantian contributions to critical philosophy, since in historical epistemology the results of science are not related to any ontological structures discovered elsewhere - be they Aristotle's categories or the formal structures of scientific theories - but only to the acts of a historically situated consciousness. For the problem of knowledge of causality and its conditions, the work of Antoine-Augustin Cournot, Essai sur les fondements de nos connaissances et sur les caractères de la critique philosophique (1851) and the work of Léon Brunschvicg, L'expérience bumaine et la causalité physique (1922) are invaluable.

\footnotetext{
8 See especially Kant 1998, 210-214 (A 76-83/B 102-109).

${ }^{9}$ See especially Cohen 2015.
} 
In the former, Cournot presents the important distinction between theoretical data and historical data (Cournot 1851, 199-200 (\$ 312)). Theoretical data are derived from the general laws put forward by scientific theories. They are necessary and deterministic, because only the facts that fall under the general laws of the theory exist as theoretical data. Theoretical data include facts derived from such concepts as natural motion in ancient physics and mass, energy and mass-energy in modern physics, to name a few examples, which all have in common the invariable features of their respective situations. In Newtonian physics, mass cannot disappear from the theoretical universe, but only change its position within it, like energy can only change its form. It is only thanks to those data that knowledge of the past, and a fortiori knowledge of ancestralities, is possible. As Meillassoux himself remarks, the means by which the age of a given object can be determined are the extremely regular laws of the radioactive decay of atomic nuclei (Meillassoux 2008, 9). The theoretical data depend therefore on the construction, taking place at the moment of the elaboration of its theory, of the total time whose flow can be examined by the theory. The condition of the existence of everything, except maybe the immediately given, is therefore the necessity of the general laws presented by the theory.

But there are also historical data: those data that are not predicted by the theory, for instance the surprising result of a measurement. Such data appear therefore as contingent in the original sense of the word as that which arrives without being announced beforehand. They are the other element by which the passing of a certain time is possible. The theoretical data provide the stable elements of time that warrant judgements that something is changing beyond the substitution of one thing for another. They are also the means by which the other types of data can be understood, like the regularity of the change of an electron's energy level can be used to measure other less regular changes. If, however, there were only such regular and predictable changes, one could say that there was no time, since everything would be determined in advance. The historical data, as that which changes within the frame of predictable change, provide thus the content of time as opposed to its form.

The importance of this distinction between historical and theoretical data lies in the fact that it dispenses the conditions of the production of scientific knowledge. Experimentation can be determined as the art of coordinating independent causal series and thus producing contingencies understood as something that arrives at something else. Any act of measurement is such an encounter of distinct causal series: for instance, the causal series regulating electron's energy level and any other causal series measured by an atomic clock. Moreover, that art consists especially in understanding the effect of hidden causal series on the one to be measured - say the effect of atmospheric pressure on the boiling point of liquids. To master that art is thus properly speaking to master contingency, i.e. to understand and manipulate the interrelation of causal series. 
But despite having made this key distinction, Cournot relapses in the end into making the same error as Meillassoux. He believes that there are sciences that correspond to theoretical data and that are therefore integrally rational. These rational sciences are the ones that grasp the interior qualities of matter, such as chemistry or crystallography. On the other hand, there are sciences that study the interactions of material entities and that Cournot designates as cosmological sciences. But this distinction of intrinsic and extrinsic qualities (like that of the ancestral and the correlated) is belied by almost every major discovery in the history of science. After the fulfilment of the Copernican revolution by Newton, there is almost nothing left of the natural motion that Aristotle attributed to bodies: the movement of a body depends only on the mass of the body, its relative position to other bodies and the mass of those other bodies. After the theory of relativity, even mass and position can no longer be considered as independent factors. After quantum physics, one can no longer separate the fact of the observation from the qualities of the observed object ${ }^{10}$. It is thus not towards a universe empty of thought that modern science evolves, but towards an increased consciousness of the effects that things and thinking beings instil on one another.

So, in order to conserve the useful kernel of Cournot's theory against his own dogmatic impulse, Brunschvicg constructs a philosophy of scientific activity in which the distinction between theoretical and historical data is constantly replaced throughout the evolution of science: a science regarded as the bedrock of scientific practice at a given time can be questioned at a later time from the point of view of another science. In the elaboration of Brunschvicg's philosophy, one can find a theorem ${ }^{11}$ that can be substituted to Meillassoux's theorem of the necessity of contingency. While deterministic laws are the prerequisite for inferential knowledge and thus for a knowledge that exceeds the present, complete determination and predictability are just as impotent as pure contingency when it comes to such knowledge, since past, present and future would be logically equivalent in the sense that every temporal moment implies all others. One must therefore allow for the possibility of the evolution of laws, as Émile Boutroux proposed in De la contingence des lois de la nature (1874), and thus for the possibility of a substitution of one determinism for another. What is not possible, however, is the removal of all lawfulness - as in the eventuality of a necessary contingency - because a contingent event can only be declared such against the background of a deterministic framework. Since, as we have seen, historical data

\footnotetext{
${ }_{10}$ Meillassoux tries in After Finitude to reconcile his theses to the results of quantum physics by arguing that the wave/particle duality or Heisenberg's uncertainty are objective mind-independent data: "the very fact that an observer can influence the law is itself a property of the law which is not supposed to depend upon the existence of an observer" (Meillassoux 2008, 114). Although such an interpretation may be possible, it disregards the novelty of quantum physics' main intuition, namely that for its object a property of a law cannot be verified without an observation that acts upon the object.
}

11 See Brunschvicg 1922, 522-3. 
presuppose theoretical data, to be contingent is nothing else than to be outside of the law. Although (following the example of Meillassoux) one could affirm in abstracto the contingency of something or even everything, such a contingency can never become the object of scientific theory. The contingent nature of an event can only be established by comparing it to the totality of the deterministic laws there are. So, to undertake such a comparison is to presuppose a rigid determinism. If, however, in accordance with Brunschvicg and Boutroux, laws are supposed to be subject to change, the establishment of a contingent event becomes strictly impossible as a result of the impossibility of any fixed set of total laws, viz. the absence of a rigid determinism. Unlike Meillassoux's theorem, Brunschvicg's is thus not based on the logical demonstration of a theoretical impossibility but on the practical impossibility of any knowledge of a pure and absolute contingency.

What becomes clear from the standpoint of Brunschvicg's philosophy of scientific activity is that transcendental limits on the deployment of science can and should be overcome. Meillassoux can be lauded for having gotten that right. These transcendental limits, however, cannot be overcome by way of another transcendental faculty, but rather through a reflection on the practical conditions of science itself. With regards to the essence of those conditions, Meillassoux is again right that they imply the contingency of laws of nature. Only this contingency cannot be absolute. Scientific knowledge must be able to push the boundaries of the lawful and the chaotic, but it cannot ever fully eliminate those boundaries without ceasing to be scientific knowledge. 


\section{Wykaz literatury}

Brassier, Ray. 2007. Nibil Unbound: Enlightenment and Extinction. Basingstoke: Palgrave McMillan.

Brunschvicg, Léon. 1922. L'expérience bumaine et la causalité physique. Paris: Alcan.

Boutroux, Émile. 1874. De la contingence des lois de la nature. Paris: Germer Baillière.

Cohen, Hermann. 2015. "The Synthetic Principles, from Kant's Theory of Experience (1885)." In The Neo-Kantian Reader. Ed. Sebastian Luft. Oxford: Routledge.

Cournot, Antoine-Augustin. 1851. Essai sur les fondements de nos connaissances et sur les caractères de la critique philosophique. Vol. 2. Paris: Hachette.

Garcia, Tristan, and Pierre-Alexandre Fradet. 2016. "Petit panorama du réalisme spéculatif." Spirale 255 (Winter): 27-30. http:// magazine-spirale.com/dossier-magazine/petitpanorama-du-realisme-speculatif.

Descartes, René. 1985a. "Meditations on First Philosophy." In The Philosophical Writings of Descartes. Vol. 2. Eds. and trans. John Cottingham, Robert Stoothoff and Dugald Murdoch. Cambridge: Cambridge University Press. - 1985b. "Principles of Philosophy." In The Philosophical Writings of Descartes. Vol. 1. Eds. and trans. John Cottingham, Robert Stoothoff and Dugald Murdoch. Cambridge: Cambridge University Press.

Harman, Graham. 2011. Quentin Meillassoux: Philosopby in the Making. Edinburgh: Edinburgh University Press.

Hegel, Georg Wilhelm Friedrich. 1977. The Phenomenology of Spirit. Trans. A.V. Miller. Oxford: Oxford University Press.

Kant, Immanuel. 1992. "On the Form and Principles of the Sensible and the Intelligible World [naugural Dissertation] (1770).” In Theoretical Philosophy, 1755-1770. Eds. and trans. David Walford and Ralf Meerbote. Cambridge: Cambridge University Press. - 1998. Critique of Pure Reason. Eds. and trans. Paul Guyer and Allen M. Wood. Cambridge: Cambridge University Press.

Locke, John. 1979. An Essay Concerning Human Understanding. Oxford: Clarendon Press. Meillassoux, Quentin. 2008. After Finitude. An Essay on the Necessity of Contingency. Trans. Ray Brassier. London \& New York: Continuum.

- 2012. The Number and the Siren: A Decipherment of Mallarmés Coup de Dés. Trans. Robin Mackay. New York: Sequence Press.

. 2015. Science Fiction and Extro-Science Fiction. Followed by "The Billiard Ball" by Isaac Asimov. Trans. Alyosha Edlebi. Minneapolis: Univocal Publishing.

Niemoczynski, Leon. 2017. Speculative Realism: An Epitome. Leeds: Kismet Press.

Zahavi, Dan. 2016. "The End of What? Phenomenology vs. Speculative Realism." International Journal of Philosophical Studies 24/3: 289-309. 
Tryggvi Örn Úlfsson - MA in contemporary European philosophy from Kingston University and Université Paris VIII Vincennes Saint-Denis and a PhD candidate at the latter university, where he prepares a thesis under the supervision of Pierre Cassou-Noguès on the philosophy of the concept as defined by Jean Cavaillès and defended by various thinkers from Léon Brunschvicg to Alain Badiou.

\section{ADRESS:}

Université Paris VIII Vincennes Saint-Denis

2 Rue de la Liberté, 93526 Saint-Denis, Francja

EMAIL: trygviorn@gmail.com

CITATION: Úlfsson, Tryggvi Örn. 2018. „Possibility of Science, Impossibility of Miracles: Léon Brunschvicg against Quentin Meillassoux . Praktyka Teoretyczna 2(28): 124-137.

DOI: $10.14746 /$ prt.2018.2.6

AUTOR: Tryggvi Örn Úlfsson

TYTUL: Możliwość nauki, niemożliwość cudów. Léon Brunschvicg przeciwko Quentinowi Meillassoux

ABSTRAKT: Tekst dowodzi, że Quentin Meillassoux wprawdzie zasługuje na uznanie za sprawą swojego projektu przedstawionego w Poza skońçonościa - ponieważ słusznie zauważa, że należy odnowić wiarę filozofii w zdolność nauki do otwierania nowych wymiarów myślenia - lecz mimo to jego propozycja posiada dwie poważne słabości. Po pierwsze, opis nauki jako tworzenia twierdzeń ancestralnych nie wydobywa istoty naukowej kreatywności. Po drugie, teza o „koniecznej przygodności” stoi w fundamentalnej sprzeczności z wiedzą naukowa. Dlatego autor artykułu przeciwstawia zasadzie koniecznej przygodności Meillassoux zasadę wydobyta z historycznej epistemologii Léon Brunschvicga i Antoine-Augustin Cournot. To znaczy, że zamiast zasady bezracji tekst broni zasady zmiennej racji bądź zmiennego rozumu (principle of a metamorphosing reason), opartej na tezie, iż żadna nieredukowalna przygodność nie jest praktycznie możliwa.

SŁOWA KLUCZOWE: Meillassoux, Brunschvicg, Cournot, przygodność, przyczynowość. 